TRENDS IN HYDROZOAN BIOLOGY - IV. C.E. MILLS, F. BOERO, A. MIGOTTO and J.M. GILI (eds.)

\title{
Photosynthetic planulae and planktonic hydroids: contrasting strategies of propagule survival*
}

\author{
PATRIZIA PAGLIARA ${ }^{1}$, JEAN BOUILLON ${ }^{2}$ and FERDINANDO BOERO ${ }^{1}$ \\ ${ }^{1}$ Dipartimento di Biologia, Stazione di Biologia Marina, Museo dell'Ambiente, Università di Lecce, 73100, Lecce, Italy. \\ ${ }^{2}$ Laboratoire de Biologie Marine, Université Libre de Bruxelles, Ave. F.D. Roosevelt 50, 1050 Bruxelles, Belgique.
}

\begin{abstract}
SUMMARY: Settlement delays can be important to prevent propagule waste when proper settling substrates are not immediately available. Under laboratory conditions, the planulae of Clytia viridicans underwent two alternative developmental patterns. Some settled on the bottom, forming a hydranth-gonotheca complex that produced up to four medusae and later either degenerated or gave rise to a hydroid colony. Other planulae settled right below the air-water interface, forming floating colonies that eventually fell to the bottom and settled. Halecium nanum released planulae with a rich population of symbiotic zooxanthellae that survived into a rearing jar for three months. After a long period of apparent quiescence (possibly fuelled by photosynthetic activities of zooxanthellae) the planulae produced new colonies. Both photosynthetic planulae and settlement at the interface air-water allow a delay in the passage from a planktonic to a fully functional benthic life.
\end{abstract}

Key words: Hydrozoa, life cycle, planula, floating hydroid, Zooxanthellae, dispersal

\section{INTRODUCTION}

Supply-side ecology (e. g., Gaines and Roughgarden, 1985) stressed the importance of organism substitution for the persistence of marine benthic communities. Individuals die and are replaced, so that the future of a community depends on the success of larval settlement. In this framework, larval ecology (usually a plankton-based affair) becomes crucial in benthic ecology and life cycles acquire a central position in marine ecology (Boero et al., 1996; Marcus and Boero, 1998).

The efficacy of dispersal of benthic organisms is linked to propagule vagility, with the possibility of delaying settlement until proper substrates become available. As remarked by Vance (1973), the planktonic larvae of benthic invertebrates can be either

*Received July 2, 1999. Accepted January 18, 2000. lecithotrophic (with their own reserves) or planktotrophic (feeding on external food sources), this affecting their possibilities of dispersal and survival. Scheltema $(1966,1988)$ described long-lived larvae of benthic invertebrates able to cross oceans: teleplanic larvae. A severe constraint to such widerange dispersal is the impossibility, for non-feeding larvae like those of most hydroidomedusae, to have the necessary reserve to lead a long larval life before settlement (see Cornelius, 1992).

Boero and Bouillon (1993) and Boero et al. (1997) reviewed the variety of hydroidomedusan cycles, describing a vast array of modifications of the classical polyp-medusa alternation: in many cases, either the medusa or the polyp can be suppressed. The primary larva in the hydroidomedusan life cycle is the planula, a stage with generally low vagility which, in some cases, even remains connected to the mother colony by mucous threads 
before settlement (Wasserthal and Wasserthal, 1973; Hughes, 1977). There are no records of feeding planulae and their settlement should occur soon after release, this limiting dispersal for species deprived of other planktonic stages, i. e. medusae. Boero and Bouillon (1993), however, remarked that the presence of a medusa in the life cycle is not correlated to wide distribution, so that other ways of dispersal are available to these animals (see also Cornelius, 1992).

In this paper we report on the life cycle features of two species, relating their developmental features to their strategies of dispersal while leading a larval or post-larval planktonic life.

\section{MATERIAL AND METHODS}

Colonies of Clytia viridicans and Halecium nanum, growing on algae of the genus Cystoseira, were collected by SCUBA diving from the rocky shore of the Ionian Sea (Porto Cesareo, Italy) during April-July (C. viridicans) and October (H. nanum) 1997. Fertile colonies were removed from the supporting algae and maintained in glass tanks with filtered seawater (FSW, $0.45 \mu \mathrm{m}$ ). Both temperature and photoperiod were controlled so to match field conditions. The medusae released in the laboratory were fed with Artemia nauplii and reared until maturity in FSW. Males and females were kept together so to have fertilisation.

The planulae, either released from the gonotheca (H. nanum) or produced in the water after fertilisation $(C$. viridicans), were maintained in glass tanks with FSW $(0.22 \mu \mathrm{m})$. The presence of zooxanthellae was investigated in vivo by a light microscope with fluorescence apparatus.

\section{RESULTS}

\section{Clytia viridicans (Leuckart, 1856)}

Metschnikoff (1886a) described a medusa that he retained as identical with those described by Leuckart in 1856 as Phialidium viridicans. Later, Metschnikoff (1886b) reported and figured primary hydranths of $C$. viridicans with a gonotheca arising from a basal plate. Both hydroid and medusan features agree with the present material. Russell (1953) considered the possibility that Clytia flavidula and C. viridicans were referable to a single species.
Later, Cornelius (1982) referred P. viridicans to $C$. hemisphaerica because of their similarity. Finally, Calder (1991) described the hydrotheca of C. hemisphaerica with "U-shaped pleat extending inwards towards hydrothecal cavity"; he also reported an extensive synonymy list for $C$. hemisphaerica, including in also P. viridicans Leuckart, 1856.

The following is the first description of the life cycle of $C$. viridicans.

Hydroid (Fig. 1a, b)

Colony stolonal, growing on algae; pedicel short, annulated at base and below hydrotheca; hydrotheca conical, about $0.6 \mathrm{~mm}$ high, with 7-9 cusps, projecting inwards and with outwards perisarc projections in the bays between nearby cusps; hydranths about $0.5 \mathrm{~mm}$ high with a peduncled hypostome and 14-18 amphicoronate tentacles, the ones oriented downwards laying on the perisarc projections between adjacent cusps, the ones oriented upwards being sustained by cusps; gonothecae on hydrorhiza, either corrugated or smooth, about $0.8 \mathrm{~mm}$ high, containing a row of up to four developing green medusae.

\section{Newly released medusa (Fig. 1c)}

Umbrella hemispherical, about $0.5 \mathrm{~mm}$ high, bright green, with four radial canals, four perradial tentacled bulbs, four small interradial bulbs sometimes present; manubrium tubular, with four lips, reaching half of subumbrellar cavity; velum wide, with a small opening; eight statocysts along the circular canal, with one statolyth each. A row of nematocysts often present on exumbrella, parallel to umbrellar margin.

\section{Medusa development (Fig. 1d)}

Gonad rudiments developed on radial canals two days after release, along with other four tentacles on interradial marginal bulbs and other statocysts between adjacent tentacles. Marginal bulbs, tentacles and statocysts are gradually added and umbrella tends to flatten until, 30-45 days after release, medusae reach maturity.

\section{Mature medusa (Fig. 1 e)}

Umbrella flattened, about $6 \mathrm{~mm}$ wide and 1.5-2 mm high, with 14/16 tentacles; manubrium, gonads and tentacular bulbs bright green, exumbrella trans- 


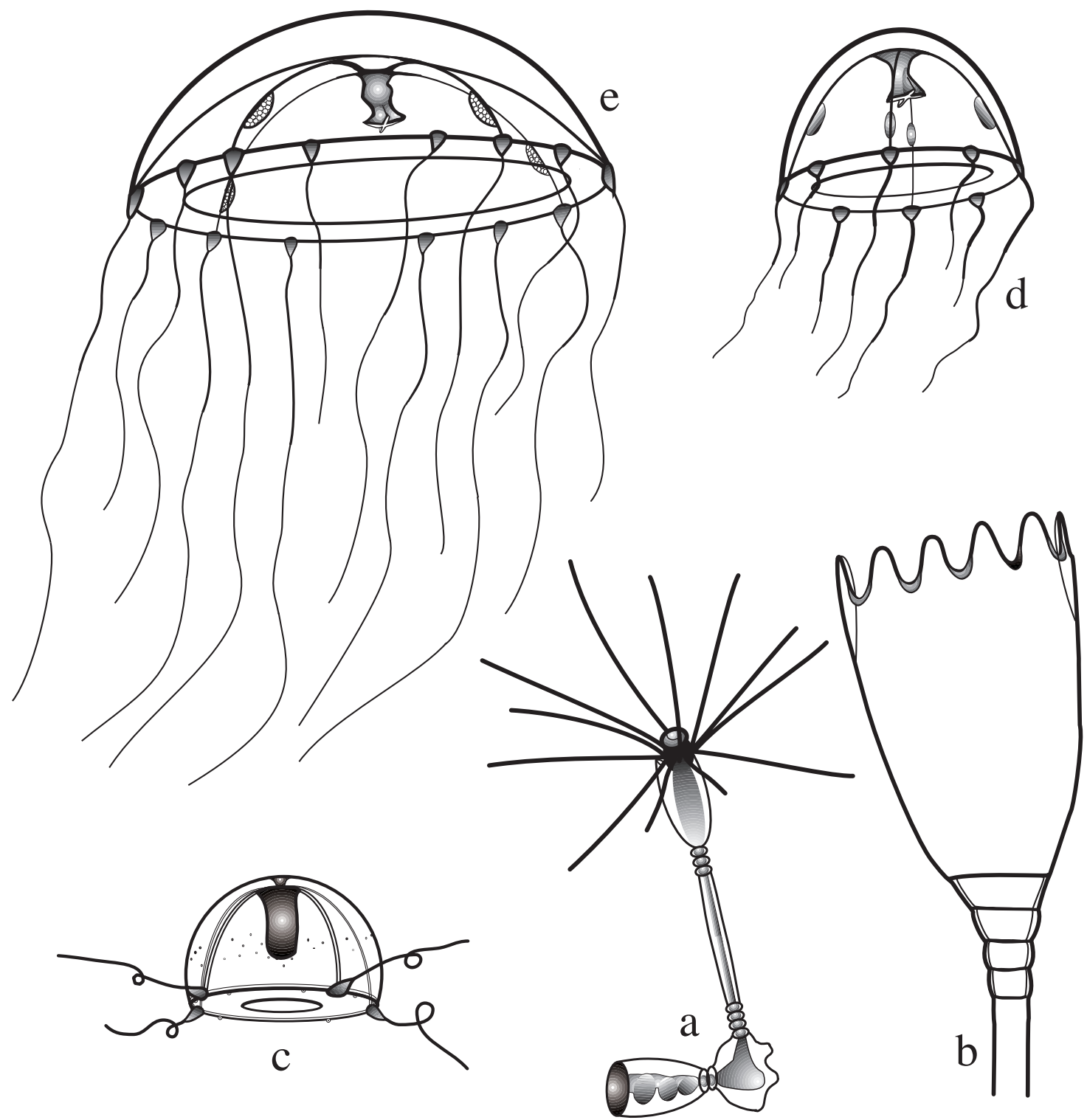

FIG. 1. - Clytia viridicans. a: primary hydranth with gonotheca; b: hydrotheca; c: newly released medusa; d: young medusa; e: mature medusa.

parent; manubrium short, on a short peduncle, mouth with four corrugated lips; gonads on distal part of radial canals, not reaching umbrellar margin.

\section{Planula production (Fig. 2)}

Spawning took place at night; the eggs, about $200 \mu \mathrm{m}$ in diameter, were immediately fertilised, and the embryos reached a gastrula stage within 10 hours, to differentiate into free-swimming hollow planulae within 20 hours. Settlement took place within 48 hours and 6-10 days after zygote formation.
Settlement on the bottom (Fig. 2)

Most planulae settled on the glass of the rearing jars, forming a wide basal disc from which a primary polyp arose within 12 hours followed, after 24 hours, by a gonotheca. Two days later, 3 or 4 medusae were released. After medusa liberation, some polyps degenerated, but most developed a hydrorhiza and new polyps, producing large colonies that started to develop gonothecae and to release medusae. Several generations were easily obtained under laboratory conditions. No differences were observed in development and growth 


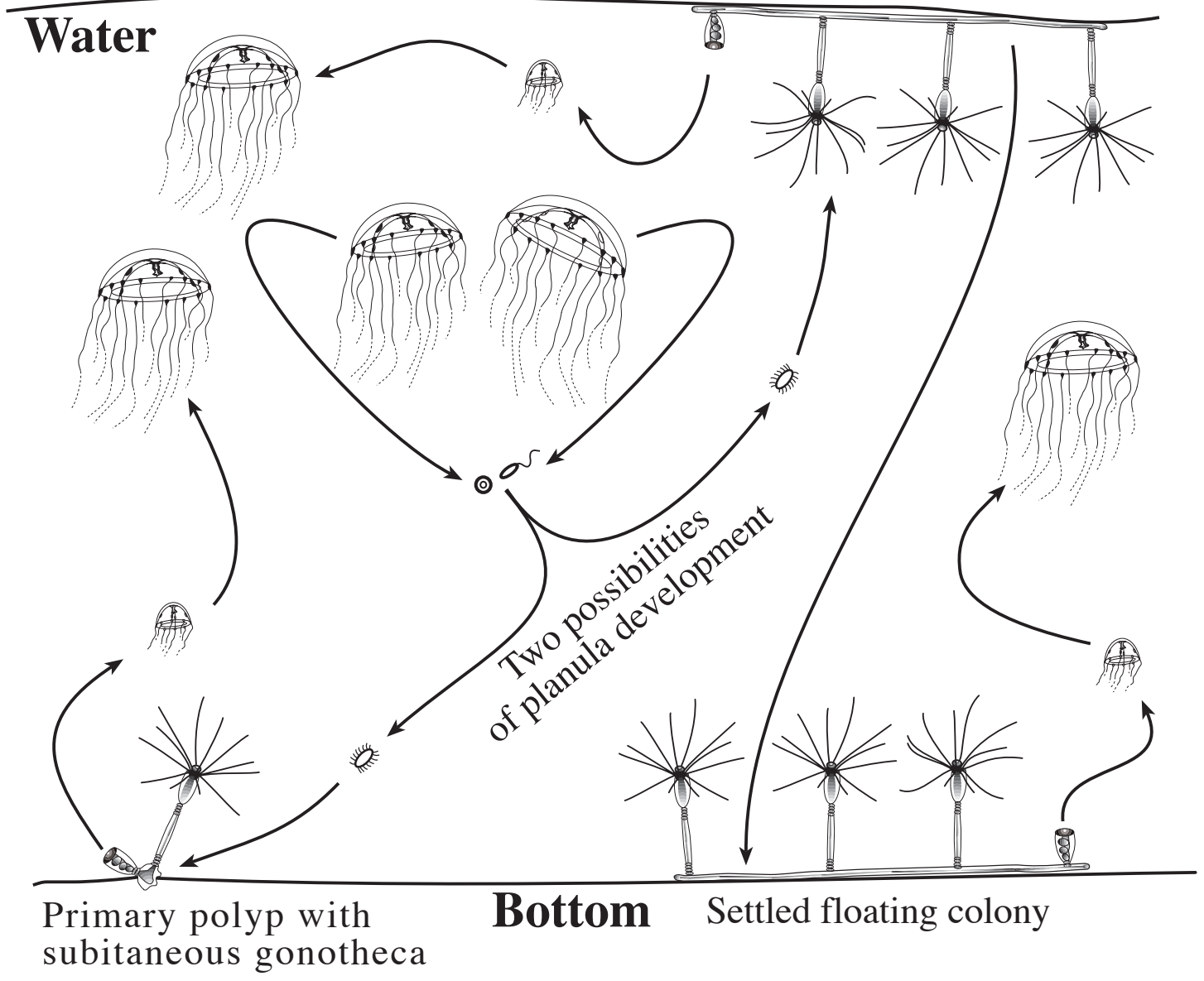

FIG. 2. - Clytia viridicans, alternative life cycle pathways involving planula settlement either on the bottom or on the air-water interface.

pattern between medusae from natural colonies and medusae from laboratory-reared ones.

\section{Settlement on air-water interface (Fig. 2)}

Some planulae settled on the underside of the surface film of water and gave rise to floating colonies that developed for weeks in that position. Accidental break off of the interface induced colony sinking to the bottom. Sunken colonies settled on the bottom of the rearing jars, becoming indistinguishable from those that immediately developed there.

\section{Remarks}

The development of gonothecae from the base of primary hydranths confirms Metschnikoff's observations. Such developmental pattern was never reported for other Clytia species, but recalls what
Bouillon et al. (1991) described for Laodicea indi$c a$. The bright green colour of the medusa, furthermore, is clearly suggested by the specific name viridicans, from the Latin viridis: green. The adult medusa is similar to Clytia hemisphaerica but the green colour of gonads, manubrium and marginal bulbs is a diagnostic character in living material. The shape of the hydrothecal cusps, with the perisarc projections between adjacent cusps, is a diagnostic character for the hydroid.

The origin of floating colonies directly from a planula is rare for usually benthic hydroids; Billard (1917) reported on three free-living species, two of which perhaps represent fragments of detached colonies, while the third species, Campanularia pelagica Van Breeman can be derived from an unsettled planula or from a planula settled on a sand grain (see also Cornelius 1995). Cornelius (1982) considered Campanularia pelagica as identical with Clytia hemisphaerica. 
Halecium nanum Alder, 1859

Together with $H$. conicum, $H$. pusillum and $H$. tenellum, Halecium nanum is one of the small Halecium of the Mediterranean. Motz-Kossowska (1911) provided a good description of this species which, in spite of being rather common, has been rarely treated in hydroid literature.

\section{Planula production}

The colonies of Halecium nanum, as well as the planula, are packed with zooxanthellae. The solid planulae, with a ciliate epidermis, moved slowly by ciliary propulsion. They also crawled on the bottom with peristaltic movements, continuously changing from an elongated to a spherical shape.

The majority of the about 100 planulae released in the laboratory died within one week, but two survived and went through the following states:

- 0-30 days: they continuously crawled on the jar bottom;

- 31-70 days: they stopped, and became nearly spherical, as if they were encysted;

- 71-75 days: they became active again, acquiring a pear shape with a pike from which, after three days, a polyp was born;

- 76-100 days: a colony with five hydranths was built.

\section{Remarks}

The colonies produced by the two planulae had zooxanthellae in their tissues and regressed to hydrorhiza within a week after settlement; they were not kept further to see if they were able to regenerate after a period of rest.

\section{DISCUSSION}

Planula dispersal is generally limited because planulae are lecitothrophic: in most hydrozoan species, in fact, planula settlement occurs within few hours or days (Sommer, 1992), so their contribution to dispersal should be little. Planula types reflect the vagility of species with and without medusae: those produced by medusae are usually hollow and able to swim, so to reach the bottom from the water column, whereas those produced by hydroids are usually solid, do not swim much and just crawl on the bottom (see Bouillon, 1994). These different properties should lead to higher endemicity in species without medusae and wider distribution in species with medusa. This is not what Boero and Bouillon (1993) found in the distribution of Mediterranean species, hypothesising a dispersive role also for the hydroid. The specialised asexual propagules of Halecium pusillum are a paradigm of hydroid dispersal (Huvé, 1955), even though many species simply disperse by colony fragments.

Medusae are obvious dispersal agents, but they can become ripe while distant from proper settling substrates for the planulae, so that sexual reproduction might result in a failure. Such inconvenient can be overcome by prolonging the life of medusae by fission, by multiple gonad ripening, or by production of gonothecae and fertile polyps on the medusa, but in Clytia viridicans this risk is faced with the possibility for the planula to produce hydroid colonies attached to the air-water interface that can become secondarily benthic.

Cornelius (1992) discussed the possibility for hydroids to settle on floating organisms and raft on them so to become widely dispersed. The efficacy of this way of dispersal has not been tested experimentally but, however, is probably very high for the hydroids that settle on algae, such as the ones we investigated. That of Clytia viridicans, with planulae producing floating hydroids, is a particular case of rafting, because the hydroid itself is the raft, contrary to what happens for the species settling on other organisms, labelled as rafters. Floating hydroids are usually originated by fragmentation of benthic colonies whereas, for $C$. viridicans, the rafting colonies derive from planulae. It might be questionable wether this planula behaviour can really occur in the field. The study of many hydrozoan species, to our knowledge, never recorded such planula behaviour whereas, in $C$. viridicans, it occurs quite often. Particularly calm conditions are common in the Mediterranean during summer months, so allowing planula settlement on the interface. Once the colony is established, then, it can even become detached from the surface and be transported by the currents.

As described for dozens of species by Boero and Fresi (1986), many hydroids deprived of medusa paradoxically, after sexual reproduction, "disappear" for several months instead of becoming more abundant. The zooxanthellate planulae of Halecium nanum, remaining viable for at least three months, are one of the keys of this lapse between planula production and appearance of new colonies. For 
species deprived of zooxanthellae, another possibility might be that planulae settle, become wrapped by perisarc and remain dormant until the return of favourable conditions.

These planula behaviours were observed in the laboratory and we do not know their importance in the field. The contribution of planulae to species dispersal, however, might be greater than usually thought and it is possible that further types of planula development will be found in the future, showing still unexpected aspects of the renewed developmental plasticity of hydrozoans.

\section{ACKNOWLEDGEMENTS}

This work was supported by grants of MURST (60\% and COFIN programs), CNR (PRISMA 2), NSF (PEET) and the Amministrazione Provinciale di Lecce.

\section{REFERENCES}

Alder, J. - 1859. Descriptions of three new species of sertularian Zoophytes. Ann. Mag. nat. Hist., 3(17): 353-355.

Billard, A. - 1917. Note sur quelques espèces d'hydroïdes libres. Bull. Mus. Hist. nat. Paris, 23 (7): 539-546.

Boero, F. and E. Fresi. - 1986. Zonation and evolution of a rocky bottom hydroid community. P.S.Z.N.I: Mar. Ecol., 7 (2): 123-150.

Boero, F. and J. Bouillon. - 1993. Zoogeography and life cycle patterns of Mediterranean hydromedusae (Cnidaria). Biol. J. Linn. Soc., 48(3): 239-266

Boero F., G. Belmonte, G. Fanelli, S. Piraino and F. Rubino. 1996. The continuity of living matter and the discontinuities of its constituents: do plankton and benthos really exist? Trends Ecol. Evol., 11(4): 53-58.

Boero, F., J. Bouillon, S. Piraino and V. Schmid. - 1997. Diversity of hydromedusan life cycle: ecological implications and evolutionary patterns. In: J.C. Den Hartog (ed.), Proceedings of the 6th International Conference on Coelenterate Biology, 1995, pp. 53-62. National Natuurhistorisch Museum, Leiden.

Bouillon, J., F. Boero and S. Fraschetti. - 1991. The life cycle of Laodicea indica (Laodiceidae, Leptomedusae, Cnidaria). In: R.B. Williams, P.F.S. Cornelius, R.G. Hughes and E.A. Robson (eds.), Coelenterate Biology: Recent Research on Cnidaria and Ctenophora. Hydrobiologia, 216/217: 151-157.

Bouillon, J. - 1994. Classe des Hydrozoaires (Hydrozoa Owen,
1843). In: P.P. Grassé (ed.), Traité de Zoologie, Tome 3(2): 29416. Masson, Paris.

Calder, D.R. - 1991. Shallow-water hydroids of Bermuda. The Thecatae, exclusive of Plumularioidea. Life Sci. Contr. R. Ontario Mus. 154: 1-140

Cornelius, P.F.S. - 1982. Hydroids and medusae of the family Campanulariidae recorded from the eastern North Atlantic, with a world synopsis of genera. Bull. Br. Mus. nat. Hist., Zool., 42(2): $37-148$.

Cornelius, P.F.S. - 1992. Medusa loss in leptolid Hydrozoan (Cnidaria) hydroid rafting, and abbreviated life-cycles among their remote-island faunae: an interim review. In: J. Bouillon, F. Boero, F. Cicogna, J.M. Gili and R.G. Hughes (eds.), Aspects of hydrozoan biology. Sci. Mar. 56(2-3): 245-261.

Cornelius, P.F.S. - 1995. North-West European Thecate Hydroids and their Medusae. Part 2. Sertulariidae to Campanulariidae. In: R.S.K. Barnes and J.H. Crothers (eds.): Synopses of the British Fauna (New Series). No 50, pp. 1-386. The Linn. Soc. London and Est. Coas. Sci. Ass. - Field Studies Council, Schrewsbury.

Gaines S.D. and Roughgarden J. - 1985. Larval settlement rate: a leading determinant of structure in an ecological community of the marine intertidal zone. Proc. Natl. Acad. Sci. USA, 82: 3707-3711.

Hughes, R.G. - 1977. Aspects of the biology and life-history of Nemertesia antennina (L.) (Hydrozoa: Plumulariidae). J. mar. biol. Ass. U.K., 57: 641-657

Huvé, P. - 1955. Sur des propagules planctoniques de l'hydroïde Halecium pusillum (Sars). Bull. Inst. océanogr. Monaco, 52 (1064): 1-12

Leuckart, R. - 1856. Beiträge zur Kenntniss der Medusenfauna von Nizza. Archiv für Naturgeschichte, 22: 1-40.

Marcus, N.H. and F. Boero - 1998. Minireview: The importance of benthic-pelagic coupling and the forgotten role of life cycles in coastal aquatic systems. Limnol. Oceanogr., 43(5): 763-768.

Metschnikoff, E. - 1886a. Medusologische mittheilungen. Arb. Zool. Inst. Univ. Wien, 6: 237-265.

Metschnikoff, E. - 1886b. Embryologische studien an medusen. Ein beitrag zur genealogie der primitive-organe. Verlag $v$. Alfred Hölder, k.k. Hof-u Universitäs-Buchhändler in Wien: 1-159.

Motz-Kossowska, S. - 1911. Contribution à la connaissance des hydraires de la Méditerranée occidentale. II.- Hydraires calyptoblastiques. Archs Zool. exp. gén. 56 (10): 325-352.

Russell, F.S. - 1953. The medusae of the British Isles. Anthomedusae, Leptomedusae, Limnomedusae, Trachymedusae and Narcomedusae. Cambridge University Press, Cambridge, pp 1-530

Scheltema, R.S. - 1966. Evidence for trans-Atlantic transport of gastropod larvae belonging to the genus Cymatium. Deep-Sea Res., $13: 83-95$.

Scheltema, R.S. - 1988. Initial evidence for the transport of teleplanic larvae of benthic invertebrates across the East Pacific Barrier. Biol. Bull., 74: 145-152.

Sommer, C. - 1992. Larval biology and dispersal of Eudendrium racemosum (Hydrozoa, Eudendriidae). In: J. Bouillon, F. Boero, F. Cicogna, J.M. Gili and R.G. Hughes (eds.), Aspects of hydrozoan biology. Sci. Mar., 56(2-3): 205-211.

Vance, R.R. - 1973. On reproductive strategies in marine benthic invertebrates. Am. Nat., 107: 339-352.

Wasserthal L.T. and W. Wasserthal - 1973. Ökologische bedeutung der schleimsekretion bei den planula-larven der Hydroidengattung Eudendrium. Mar. Biol., 22: 341-345. 